\title{
Hydro-Climatic Variability and Human Activities Impact on the Morphology of the Cavally River Bed, Western Côte d'Ivoire
}

\author{
Brou Loukou Alexis ${ }^{1}$, Kouassi Kouakou Lazare' ${ }^{1}$, Yao Affoué Berthe ${ }^{1}$, Kouadio Zilé Alex ${ }^{1}$, \\ Konan Kouakou Séraphin ${ }^{1}$, Konan Koffi Félix ${ }^{1}$, Kamagate Bamory², Koné Diakaria ${ }^{3}$ \\ ${ }^{1}$ Department of Geology, Laboratory of Sciences and Technology of Environment, University Jean Lorougnon GUEDE, Daloa, \\ Daloa, Côte d'Ivoire \\ ${ }^{2}$ Université Nangui-Abrogoua, Abidjan, Côte d'Ivoire \\ ${ }^{3}$ Office National de l'Eau Potable (ONEP), Direction des Ressources en Eau, Abidjan, Côte d'Ivoire \\ Email: ^brou.alexis@ujlg.edu.ci
}

How to cite this paper: Alexis, B.L., Lazare, K.K., Berthe, Y.A., Alex, K.Z., Séraphin, K.K., Félix, K.K., Bamory, K. and Diakaria, K. (2019) Hydro-Climatic Variability and Human Activities Impact on the Morphology of the Cavally River Bed, Western Côte d'Ivoire. Open Access Library Journal, 6: e5629.

https://doi.org/10.4236/oalib.1105629

Received: July 23, 2019

Accepted: September 21, 2019

Published: September 24, 2019

Copyright $\odot 2019$ by author(s) and Open Access Library Inc.

This work is licensed under the Creative Commons Attribution International License (CC BY 4.0).

http://creativecommons.org/licenses/by/4.0/

\begin{abstract}
The Cavally watershed is covered by a large forest area, where for decades there has been intense agricultural and mining activity (modern and traditional). Anthropogenic pressures and hydro climatic variability can significantly alter the hydrological response of the Cavally River watershed. The objective of this study is to assess the impact of hydro climatic variability and land-use dynamics on the availability of water resources in the Cavally River basin. To achieve this objective, two methodological approaches were used, a first approach was used to calculate the rainfall and hydrometric indices to determine the different hydro-climatic trends of the watershed. The second approach consists in analyzing the inter-annual morphological evolution of the bed of the Cavally River by using Landsat images from 1986s, 2011s and 2018s. The results of this study show that several successive years of drought were observed in the Cavally Basin from 1970 to 1980. Analysis of hydro-climatic trends showed that rainfall has declined, and the land use map analysis showed that the vegetation cover has been significantly degraded (Four common land use classes were finally mapped. They are represented by dense vegetation with $13.11 \%$; degraded vegetation and crops with $72.04 \%$; water with 4.73\%; built areas and bare soils with $10.12 \%$ ). About the evolution of the Cavally River bed, illegal gold miners could be the cause of the increase in the surface area of the water body located between the SMI and the Floleu village (Section 3 where the morphology of the Cavally River bed has increased considerably by $13.70 \%$ between 1986 and 2011 and by $55.93 \%$ between 2011 and 2018). Indeed, this area is frequented daily by gold miners who carry out their activities both in the minor bed and on the banks of the river.
\end{abstract}




\section{Subject Areas}

Hydrology

\section{Keywords}

Land Cover, Hydro Climatic Variability, Human Activities, Cavally River, Côte d'Ivoire

\section{Introduction}

Water environment deterioration is a prominent issue in river basin management throughout the world, which has become a serious threat to water security [1]. Surface water was gradually polluted due to natural and anthropogenic activities [2], such as water-rock interactions [3], industrial and municipal waste water emissions [4], nutrient losses [5], excessive dam and sluice constructions [6]. Water resources are sensitive to climate change and variability [7]. In recent years, the question of hydro-climatic variability is a challenge for the world and for African Countries in particular. It is explained by factors inherent to the climate system and the climatic variability greatly affects water resources with consequences on various sectors of activity [8]. Also, the hydrological cycle and water systems are extensively influenced by climate variability and human activities [9] [10] [11] [12]. Also, changing weather patterns will have complex and nonlinear impacts on many human and environmental systems, including on processes governing the mobilization and transport of sediment within watersheds [13]. Changing climate is an additional stressor that can enhance the effects of these anthropogenic influences [14]. For example, higher temperatures lead to increased evapotranspiration and thus, if not counterbalanced by increased precipitation, to declining streamflow [15] [16]. The Cavally watershed is covered by a large forest area, where for decades there has been intense agricultural and mining activity (modern and traditional). As mining activity is a source of considerable environmental and health impacts and issues, which vary according to the ecological context, extraction methods and type of ore, codes are very important to regulate this sector [17]. Despite the measures taken by the State, this sector is facing several difficulties, particularly those related to gold panning. The illegally artisanal gold mining activity is a very lucrative activity in which many actors, operating at various levels and with specific roles, find their financial benefit [18]. The other causes of the development of clandestine gold mining are the under-selling of traditional agricultural products (cocoa and coffee) and the ignorance of the negative medium and long-term impacts of gold panning on the biophysical and human environment by most of the actors involved in the sector. The latter aspect is observed in Zouan-Hounien, in the west of Côte d'Ivoire where the bed of the Cavally River stream is the place where this activity is developed. Gold panning is not in itself a bad activity, but the tech- 
nologies used, the technologies used are not adapted and the tools are rudimentary ("hunter-gatherer" approach). This new way of practicing gold panning raises questions about the impacts of this activity on certain characteristics of the watercourse (velocities, flow, etc.). The objective of this study is to assess the impact of hydro climatic variability and land-use dynamics on the availability of water resources in the Cavally River basin.

\section{Material and Methods}

\subsection{Study Area}

The Cavally River is a lower cross border watershed between Guinea, Ivory Coast and Liberia. Located in the west of Ivory Coast, the Cavally River begins in Guinea, in the North of Mount Nimba with more than 1000 meters as approximate altitude (Figure 1). $700 \mathrm{~km}$ long, its riverbed constitutes the border between Liberia and Ivory Coast from its middle way (at the South of Toulépleu) on about $330 \mathrm{~km}$. The lower watershed covers a complete area of $28,800 \mathrm{Sq}$. Km at Tate hydrometric station located at $60 \mathrm{~km}$ from the mouth. Côte d'Ivoire doesn't possess but about 15,000 Sq. km of watershed [19]. In the framework of this study, the chosen outlet is the hydrometric station of Floleu located at downstream of the Ity station in the Zouan-Hounien region. The low watershed has got an area of 3647.53 Sq. km (Figure 1). The region of Zouan-Hounien is in the mountain region of Côte d'Ivoire; its relief is hilly. Zouan-Hounien is in the forest area and its climate is the mountain climate with two seasons: one rainy season from May to October and one dry season from November to March. The annual average temperature is $25.6^{\circ} \mathrm{C}$. The annual average precipitation is 186 $\mathrm{mm}$. The driest month is January with a precipitation of $15 \mathrm{~mm}$. The most important precipitations are recorded in September and they are $357 \mathrm{~mm}$ in average.

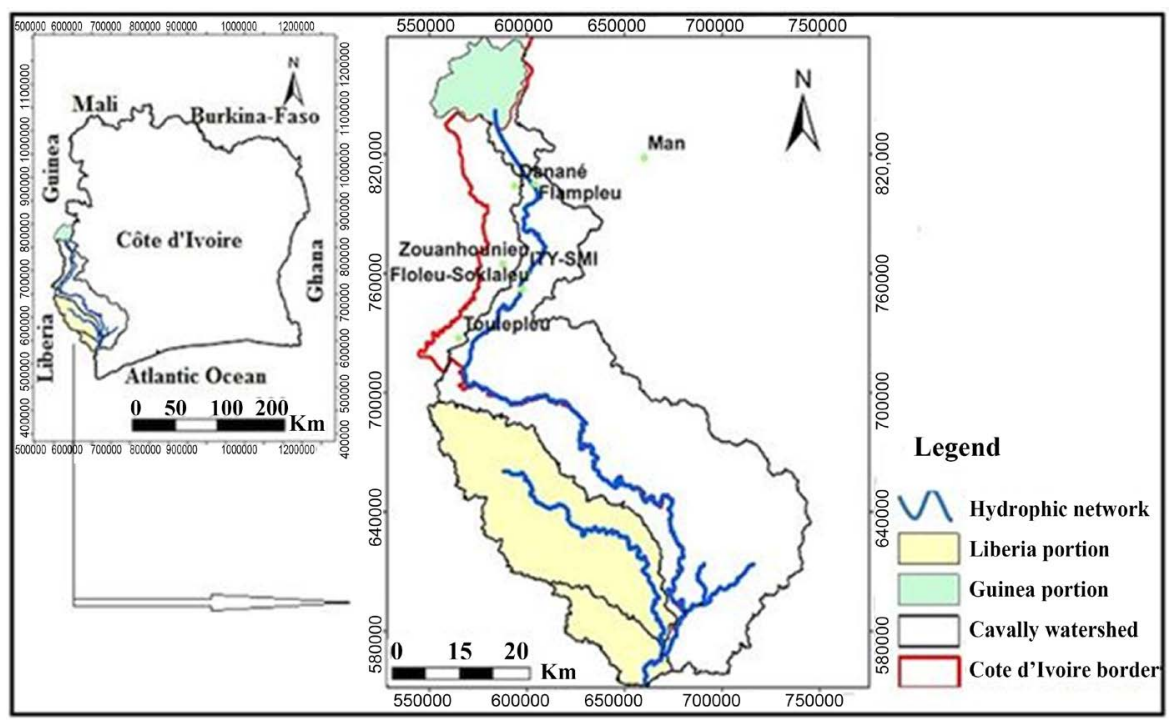

Figure 1. Study area of sub-watershed of Cavally River. 


\subsection{Data Collection and Analysis}

The methodological approach used is based on annual rainfall data. The rainfall data used are those of Danané, Toulepleu and Zouan-Hounien meteorological stations and three (3) hydrometric stations (Flampleu (Danané), Ity (Zouan-Hounien) and Toulepleu). They cover the period 1970-2010. To carry out this study, two methods were used: a first approach was used to calculate the rainfall and hydrometric index to determine the different hydro-climatic trends of the watershed. The study of hydro-climatic variability was carried out by analysing data collected at the stations. Based on the rainfall variability, periods of rainfall deficit over time and space have been identified. The second approach consists in analyzing the inter-annual morphological evolution of the bed of the Cavally River.

\subsection{Index Precipitation Methods}

The evolution of precipitation and runoff was carried out by the method of calculating the NICHOLSON rainfall index (Equation (1)) and the low-pass filter method of "HANNING of order 2" (Equation (2)) where they expressed by the following equations.

$$
I=\frac{x_{i}-\bar{x}}{\sigma}
$$

with $I$ : rainfall or hydrological index, $x_{i}$ : annual module of the variable recorded during year $I, \bar{x}$ : interannual mean of the variable over the period of study, $\sigma$ : standard deviation of the hydro-climatic series over the period of study. For HANNING'S Low Pass filter method, the first step is to filter the data to eliminate seasonal variation. This filter is made using the recommended equations. According to this method, each term in the series is calculated as follows:

$$
X(t)=0.06 x_{(t-2)}+0.25 x_{(t-1)}+0.38 x_{(t)}+0.25 x_{(t+1)}+0.06 x_{(t+2)}
$$

$X(t): X(t)$ is the weighted rainfall total of the term $t, X_{(t-2)}$ and $X_{(t-1)}$ : total observed flows of two terms immediately preceding the term $t . X_{(t+2)}$ and $X_{(t+1)}$ : observed rainfall totals of two terms immediately following the term $\mathrm{t}$. The first two $\left[X_{(1)}, X_{(2)}\right]$ and the last two $\left[X_{(n-1)}, X_{(n)}\right]$ terms of the series are calculated using the following expressions (being the size of the series):

$$
\begin{gathered}
X_{1}=0.54 x_{1}+0.46 x_{2} \\
X_{2}=0.25 x_{1}+0.5 x_{2}+0.25 x_{3} \\
X_{n-1}=0.25 x_{(n-2)}+0.5 x_{(n-1)}+0.25 x_{n} \\
X_{n}=0.54 x_{n}+0.46 x_{(n-1)}
\end{gathered}
$$

To better visualize periods of a deficit and excess flow, moving averages are centered and reduced by the following formula:

$$
Y_{t}^{\prime}=\left(x_{t}-m\right) / \sigma
$$

where: $m$ is the average of the series of weighted averages and $\sigma$ is the stan- 
dard deviation of the series of weighted moving averages.

\subsection{Decadal Variability of Rainfall over the Basin}

The annual average rainfall distribution was calculated by the isohyet method over the period 1970 to 2010 .

Rainfall data from stations in the basin and surrounding areas made it possible to trace the isohyets of the 1971-1980, 1981-1990, 1991-2000 and 2001-2010 decades. They are prepared with the maximum likelihood that considers the region, the hydrographic network and the quality of the measurements.

\subsection{Morphological Evolution of the Cavally River Bed}

The satellite images are made up of three scenes from the Landsat sensor (Land Satellite) from the website http://earthexplorer.usgs.gov. The scenes use the visible $(B, R, V)$ and near infrared bands were taken on January 07, 1986, January 12, 2011 and January 22, 2018 respectively. This month's choice (January) allows the river environment to the same season and to minimize the risk of over-or underestimating the contours of the reservoir. Indeed, the surface area of a water body may also be underestimated by the presence of aquatic vegetation or overestimated by the presence of wet soils surrounding the water bodies during the recession period [20]. In addition, Landsat 4.5 and 8 satellites provide images that include near-infrared spectral bands. This is very important because water surfaces absorb all this type of radiation [20]. The image processing consisted in making the coloured composition of the different images, vectorizing the contours of the plan each year and validating the vectorizations. About the colour composition, the bands used are respectively bands 4; 5 and 6, for the 2018 and 3 satellite images; 4 and 5 for the 2011 and 1986 images. These bands were used for the red, green and blue channels respectively. This classification brings out the different entities of the image as well as possible. The outline of the watercourse was delimited by digitalization (vectorization) using a GIS tool. The digitalization consisted, from each image used, in reviewing the outlines of the watercourse. A validation of the vectorization layers is required after the realization of these layers. Thus, the 2011 and 2018 contour vectorizations were respectively checked with the ortho image of 03/12/2012 and the Google earth image of 19/01/2018. To do this, segments parallel to the horizontal (transverse) were drawn and measured at precise and easily identifiable locations on the map, including areas of curvature. Cross-sectional segments prevent errors related to the length of the segments that could be caused by the existence of different measuring angles. The plots were validated if and only if the difference between the lengths of the segments measured on the reference images and the vectorized layers is less than $5 \%$. Otherwise the vectorizations are taken over and the segments are recalculated. After the map was validated, sections were defined to evaluate the area most affected by the gold panning phenomenon. A total of five sections were defined on the stream; one upstream section of the study area, 
three sections in the study area and one downstream section of the study area. The area of each section of the stream for the three years (1986, 2011 and 2018) was determined using the GIS tool. Indeed, the calculation of surfaces is a statistical method for estimating the level of evolution of the river bed [20].

$$
I(\%)=\frac{S_{f}-S_{i}}{S_{i}} \times 100
$$

where, $I$ is increase area (\%), $S_{f}$ et $S_{i}(\mathrm{Sq} \mathrm{Km})$ are the surfaces calculated for the final and initial years considered.

Figure 2 shows a summary diagram of all the activities carried out to achieve the interannual morphological evolution of the Cavally river.

\section{Results and Discussion}

\subsection{Distribution of Annual Rainfall from the Cavally Watershed}

Figure 3 shows the distribution of annual rainfall from the Cavally Basin. The average annual rainfall from the Cavally Basin is $1804.29 \pm 47.63 \mathrm{~mm}$.

\subsection{Decadal Variability of Rainfall of the Cavally Watershed}

The study of decadal rainfall variability from the isohyets of the 1971-1980, 1981-1990, 1991-2000 and 2001-2010 decades shows a general increase in rainfall for the 11 rainfall stations (Figure 4).

The decade 1971-1980 was made by the presence of isohyets characteristic of rainfall amounts between $1500 \mathrm{~mm}$ and $1850 \mathrm{~mm}$. The rainfall stations of Toulepleu, Guiglo and Bangolo are the only ones with the lowest rainfall $(1500 \mathrm{~mm})$;

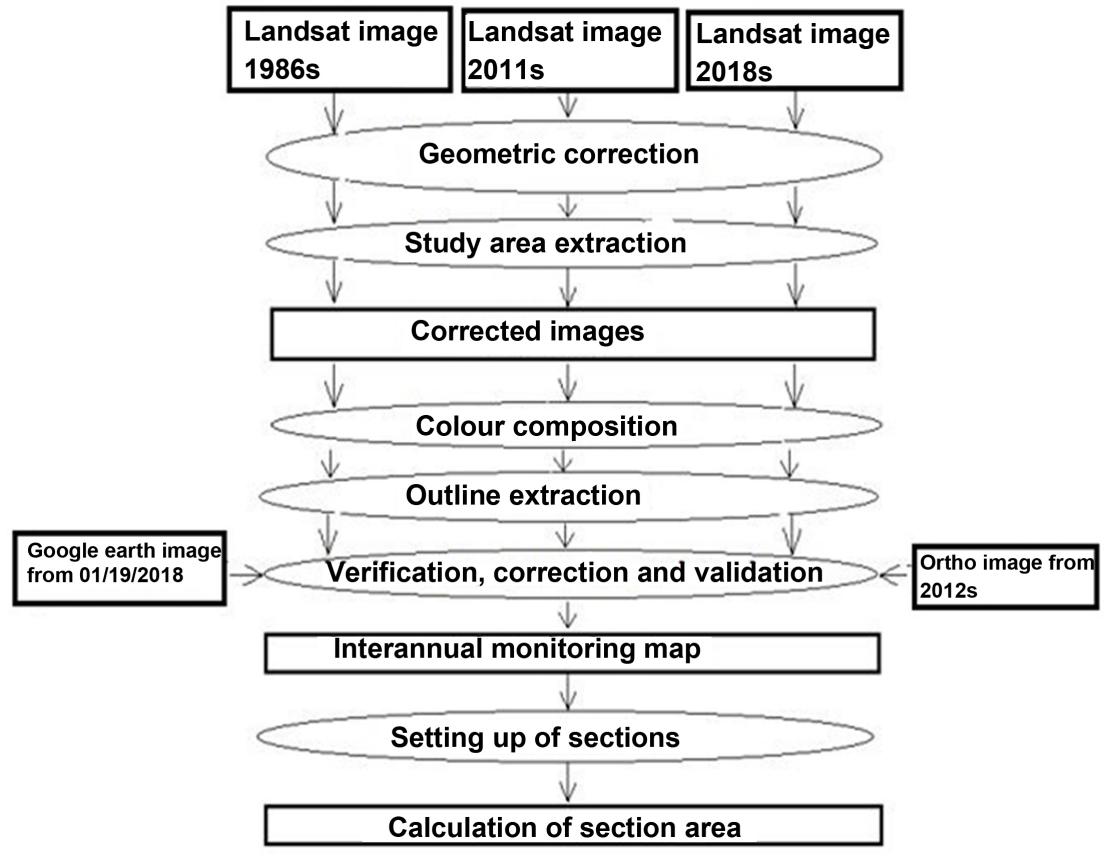

Figure 2. Conceptual diagram of the implementation of the inter-annual evolution of the bed of the Cavally River watercourse. 


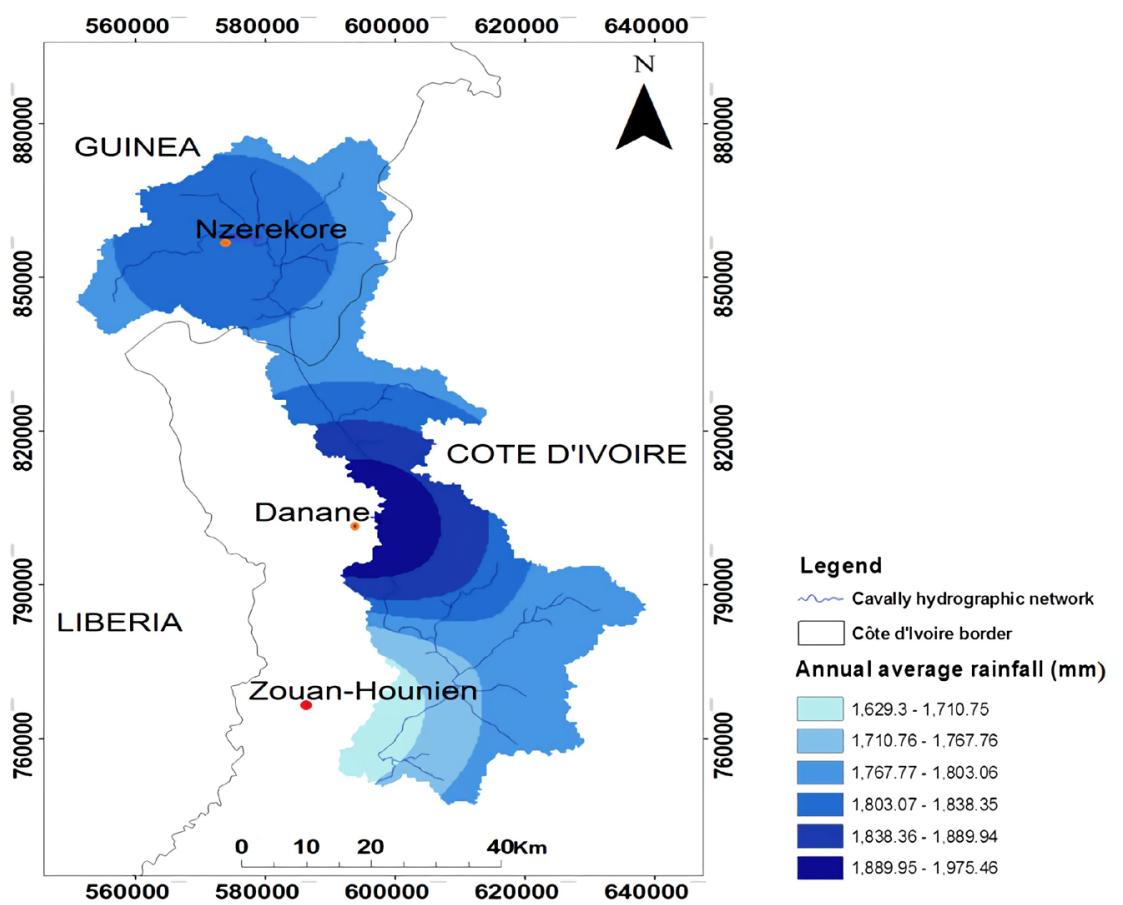

Figure 3. Annual average rainfall of Cavally sub watershed (1970-2010).
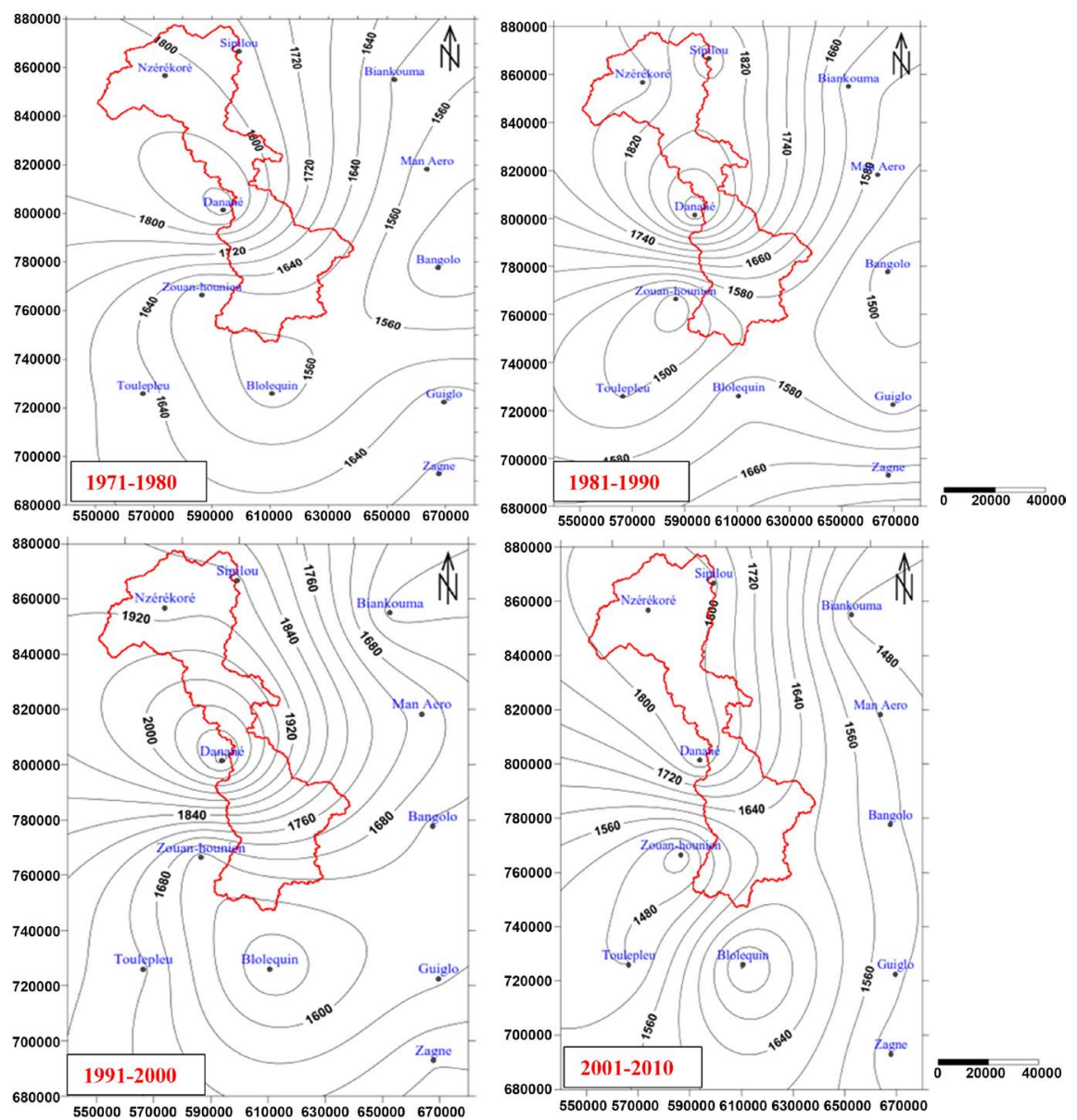

Figure 4. Maps of the decade isohyets 1971-1980, 1981-1990, 1991-2000 and 2001-2010. 
the other stations receive rainfall amounts between 1600 and $1850 \mathrm{~mm}$. The decade 1981-1990 saw an increase in rainfall with the appearance of isohyets $1700 \mathrm{~mm}, 1850 \mathrm{~mm}$ and $1900 \mathrm{~mm}$. The decade 1991-2000 also saw an increase in rainfall with the appearance of isohyets $1950 \mathrm{~mm}$ and $2000 \mathrm{~mm}$ in the Danané and Tai areas. The decade 2001-2010 also recorded an increase in rainfall similar to the decade 1991-2000 with the appearance of the $1950 \mathrm{~mm}$ and $2000 \mathrm{~mm}$ isohyets.

This could be explained by the return to normal rainfall in western Côte d'Ivoire, following the major rainfall breaks observed in West Africa from the 1960s and 1970s.

\subsection{Index Precipitation}

The evolution of Nicholson indices associated with seasonal elimination by HANNING filter shows that inter-annual variations in rainfall at the Nzerekore, Danané, Zouan-Hounien and Toulepleu stations are characterized alternating wet, normal years and dry season.

The analysis of the Nicholson indices and the 2nd order HANNING filter makes it possible to distinguish 3 climatic trends at the Toulepleu station: from 1971 to 1980 for wet period, 1981 to 1992 dry season and 1993 to 1994 to 1998 wet season. 3 periods for wet season and 4dry periods at Danané station. 3 periods for wet season and 4 dry periods at Zouan-Hounien station. Trends at the Nzerekore station vary rapidly from one period to another (Figure 5).
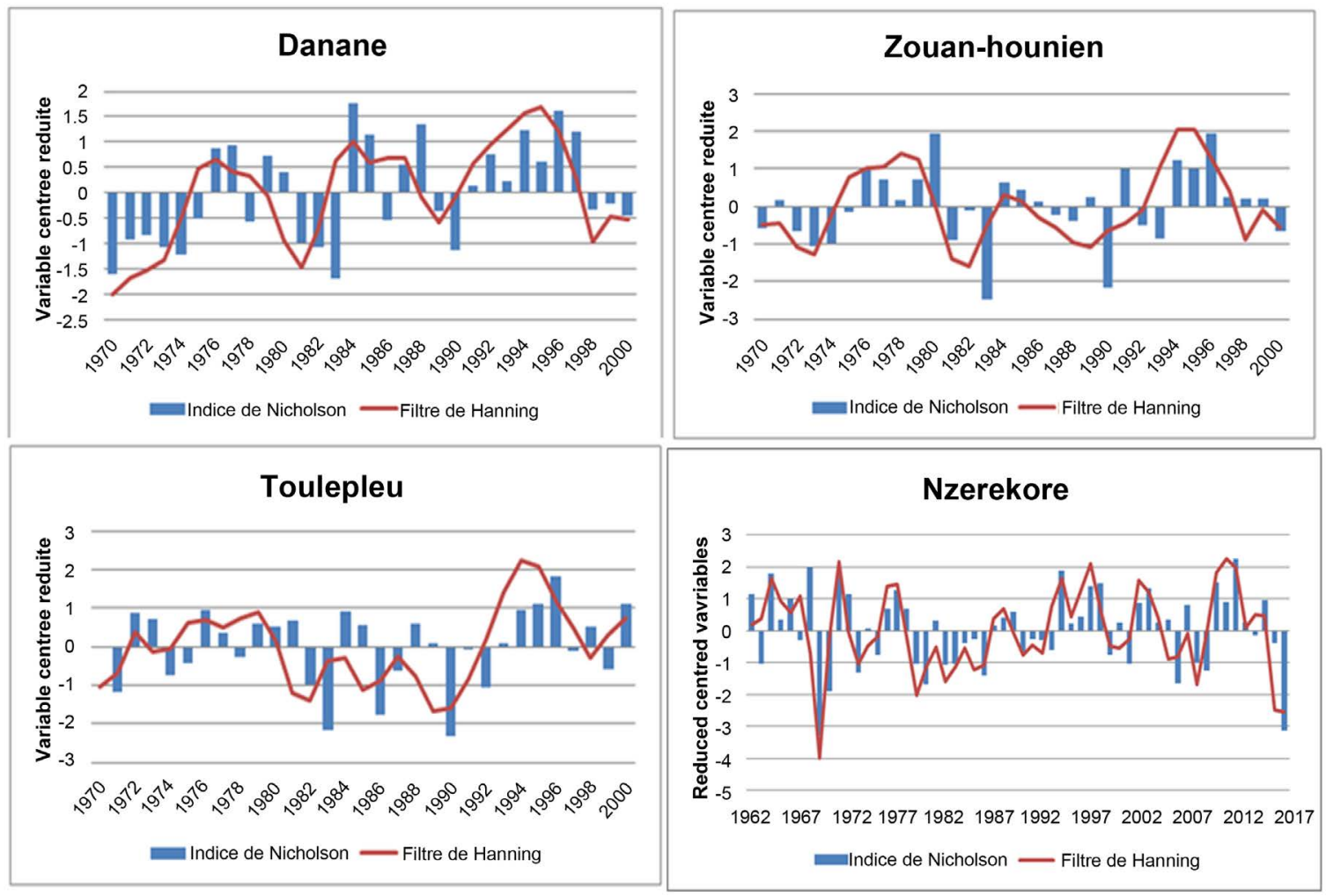

Figure 5. Annual rainfall for four stations from Cavally watershed. 


\subsection{Inter-Annual Variation in Flows of the Cavally River}

Flampleu station was chosen to monitor the hydrological variability of the Cavally watershed for the length of its series. The evolution of the reduced centred indices and Hanning filtering makes it possible to distinguish the periods of fluctuations from the following annual flow modules (Figure 6):

- a deficit period from 1974 to 1991, marked by a sharp drop in flows indicating a dry period;

- a surplus period from 1992 to 1999 , corresponding to a wet period marked by abundant flows;

- a deficit period from 2001 to 2011, indicating a dry period with a considerable decrease in flows;

- a surplus period from 2012 to 2015 , announcing a return of humidity at the end of the observation period.

\subsection{Morphology of the Cavally River Bed}

\subsubsection{Land Use Map of the Study Area}

Four (4) common land use classes were finally mapped (Figure 7). They are represented by dense vegetation with $13.11 \%$; degraded vegetation and crops with $72.04 \%$; water with $4.73 \%$; built areas and bare soils with $10.12 \%$. Discrimination between the different thematic classes is statistically significant with overall statistical accuracy ranging from $80.5 \%$ to $82.2 \%$.

\subsubsection{Dynamic Evolution of the Cavally River Bed}

Figure 8 shows the deformations of the streambed in this area on these three dates. The bed of the Cavally River stream in the Zouan-Hounien area underwent a change from 1986 to 2018. The contours of the Cavally River from 1986 (yellow) and 2011 (red) are very similar. Some deviations from these contours are observed in some areas of the watercourse. However, the contours of the 2018 watercourse (blue) show remarkable deformations.

Figure 9 shows the illegal gold miners operating and degradation of the bank of the Cavally River dues to this activity.

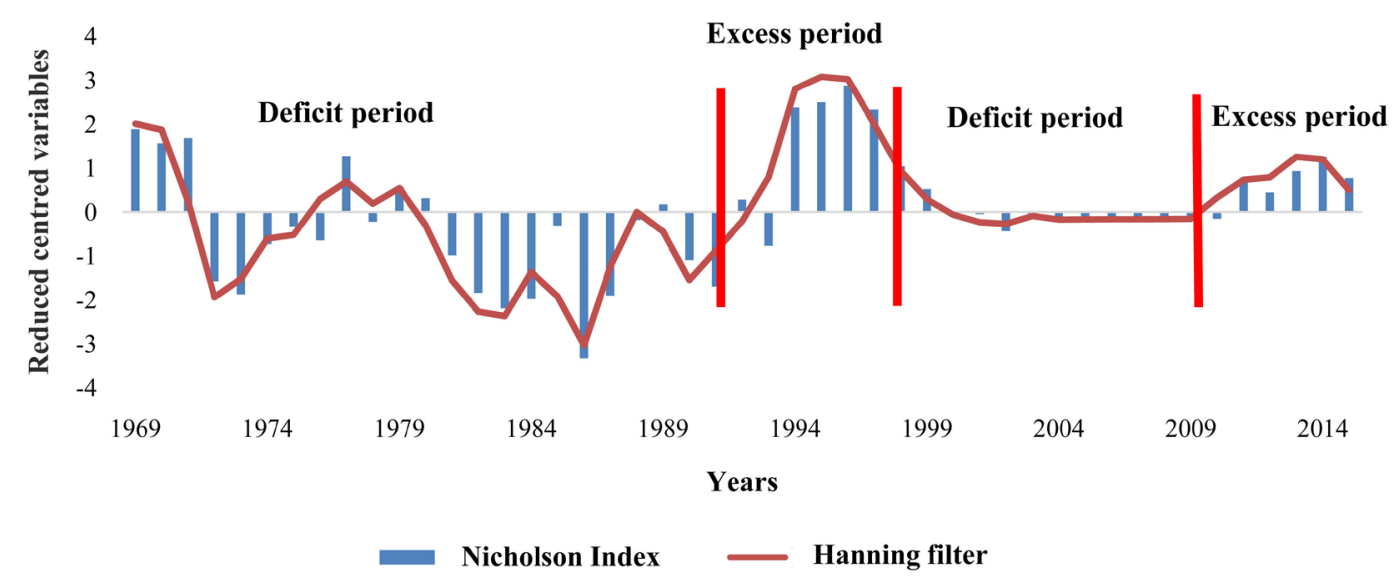

Figure 6. Variation of annual modules of the Cavally River flows to Flampleu Station (1969-2015). 


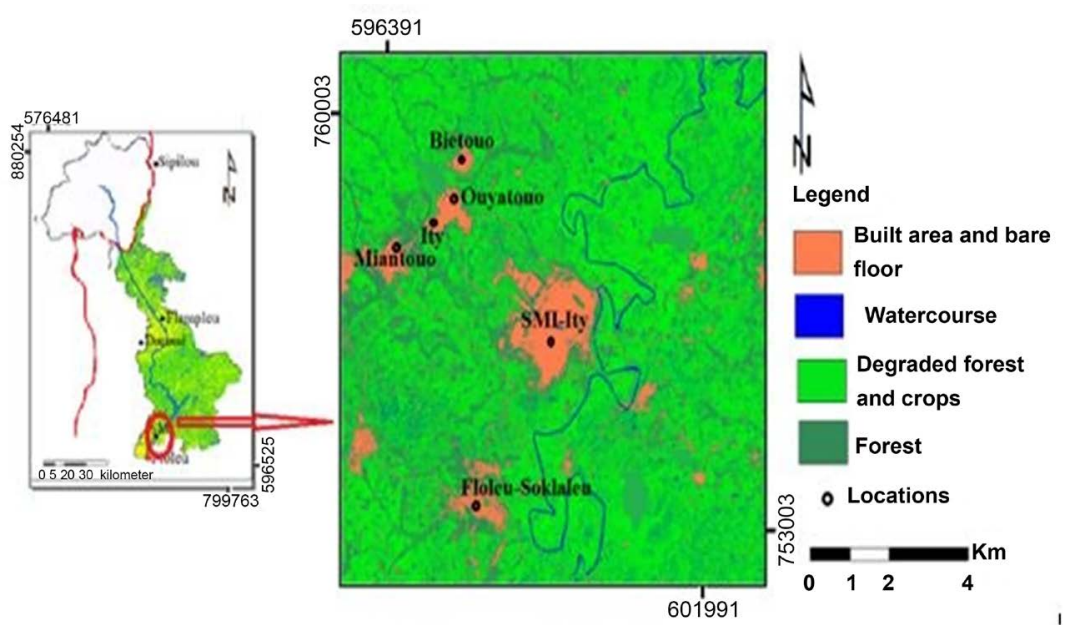

Figure 7. Land use map of the study area.

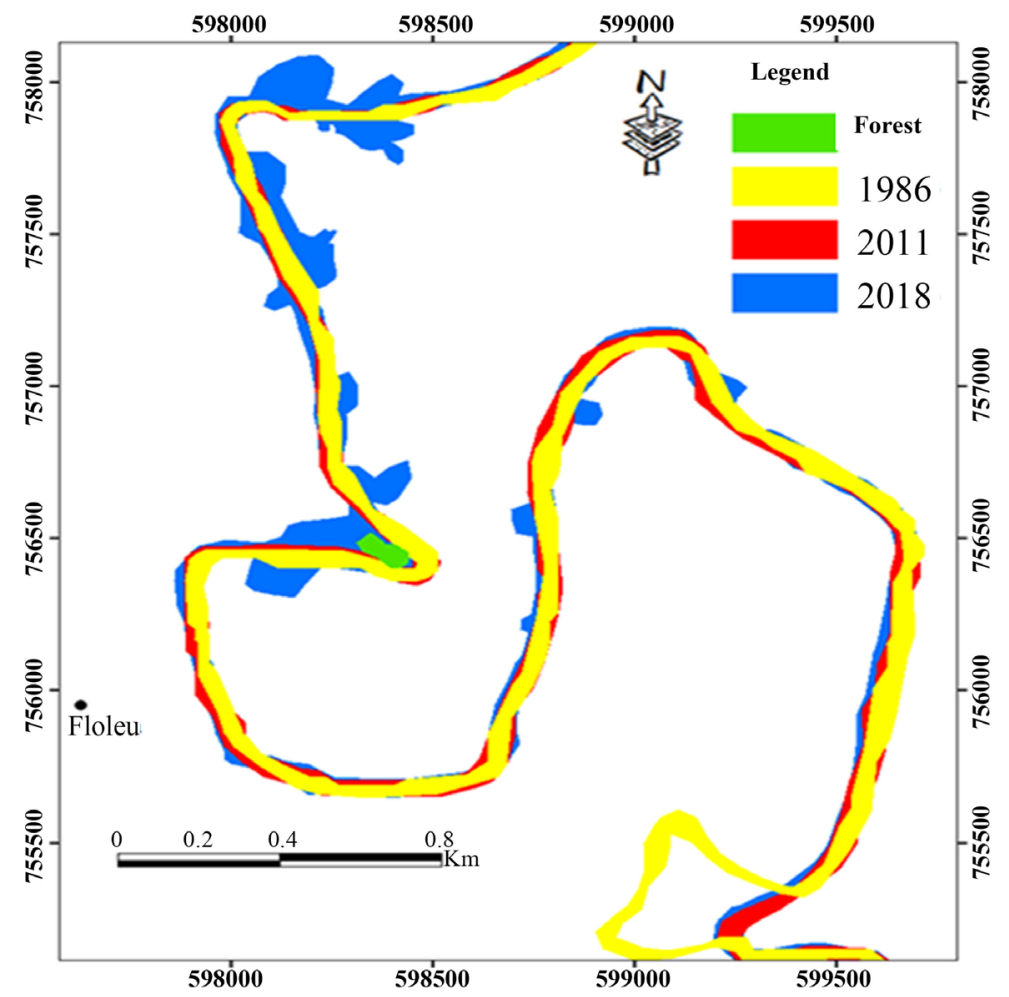

Figure 8. Inter-annual monitoring map of the Cavally River streambed from 1986, 2011 and 2018 in Section 3.

\subsubsection{Evolution of the River Bed}

The areas of the sections of the stream increased from 1986 to 2018. From 1986 to 2011 , the surfaces of the sections increased from $3.33 \%$ to $18.18 \%$. Sections 2 and 3 have a surface change of more than $10 \%$, which are $18.18 \%$ and $17.65 \%$ respectively. Between 2011 and 2018, the increase in section surfaces ranged from $19.35 \%$ to $55.00 \%$. The rates of increase in Sections 1 and 5, which are $17.65 \%$ and $12.50 \%$ respectively, are the lowest, while the rate in Section 3 (55.00\%) is the highest (Table 1 ). 


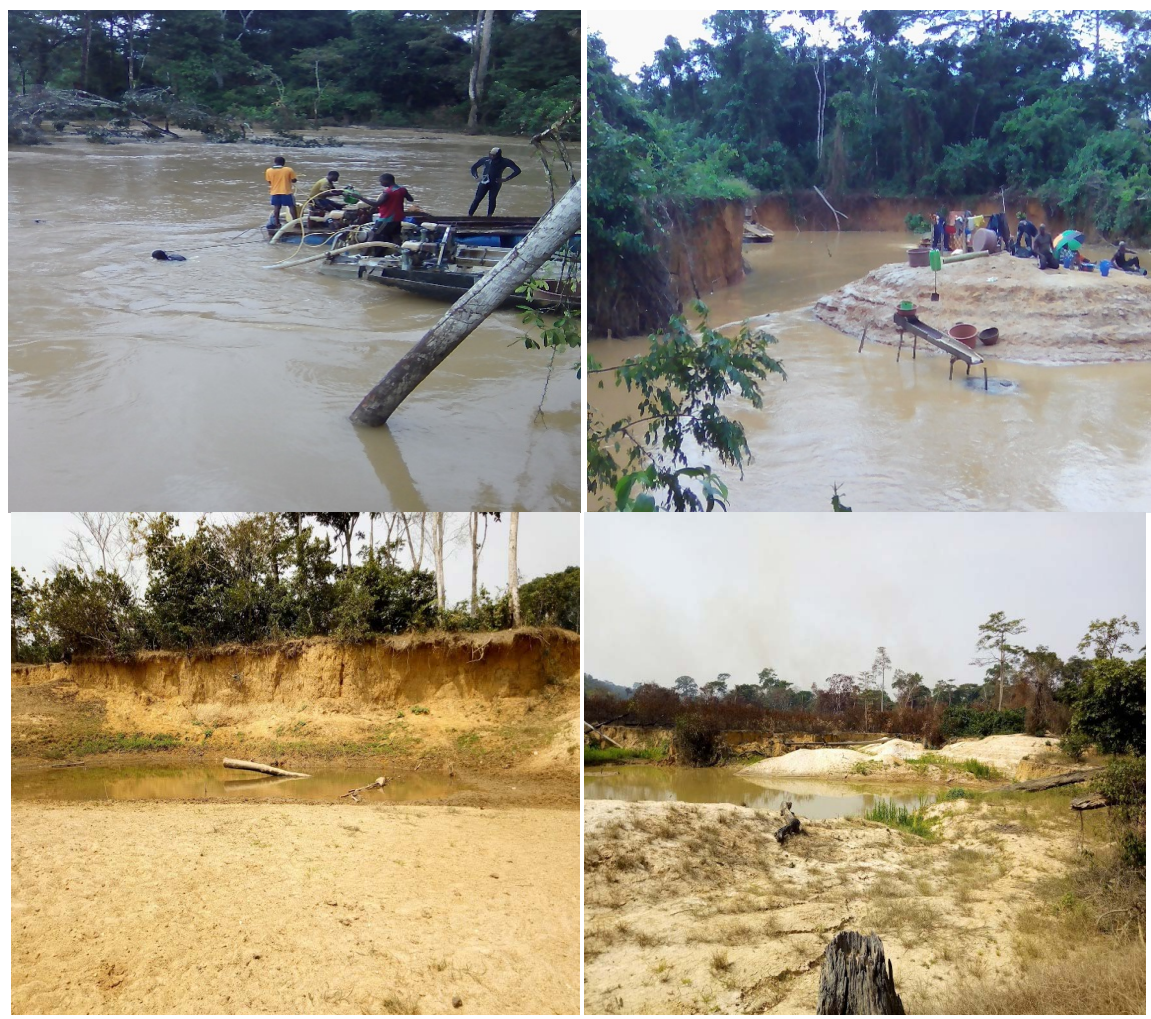

Figure 9. Degradation of the banks of the Cavally River due to illegal gold panning activities.

Table 1. Summary table of section surfaces.

\begin{tabular}{ccccccc}
\hline & & \multicolumn{3}{c}{ Area (Sq Km) } & \multicolumn{2}{c}{ Increase area (\%) } \\
\hline \multirow{2}{*}{ Upstream } & & 1986 & 2011 & 2018 & $1986-2011$ & $2011-2018$ \\
& Section 1 & 0.30 & 0.31 & 0.37 & 3.33 & 19.35 \\
& Section 2 & 0.11 & 0.13 & 0.16 & 18.18 & 23.08 \\
\multirow{2}{*}{ Study area } & Section 3 & 0.17 & 0.20 & 0.31 & 17.65 & 55.00 \\
& Section 4 & 0.39 & 0.41 & 0.51 & 5.13 & 24.39 \\
Downstream & Section 5 & 0.30 & 0.32 & 0.36 & 6.67 & 12.50 \\
\hline
\end{tabular}

The dynamics of the Cavally River watercourse in the study area were determined using Landsat images. These types of images, with very high resolutions (30 $\mathrm{m}$ of resolution), have made it possible to establish, with sufficient precision, the annual interannual monitoring of the Cavally River. Mapping water bodies using Landsat images is an accurate method, both recent and old. Thus, in Burkina Faso and Tunisia, for monitoring the configuration of water bodies over several years, [20] [21] [22] used these types of images. However, the vectorization of the contours of the water body remains a rather tedious task to accomplish because of the quality of the image. This generally leads to an underestimation or overestimation of the volume of the water body. To overcome these consequences, orthophotos and aerial photographs are needed to facilitate the estab- 
lishment of water body boundaries [23] [24]. Since these two types of photographs have a relatively low spatial resolution $(0.5 \mathrm{~m}$ resolution), this would make it possible to differentiate between the different elements of the earth's surface and to highlight water bodies and vegetation clearly.

In general, the validation of results from GIS processing is carried out through field visits [25] [26]. In this study, the data used to validate the different contour layers are of a cartographic type. However, they were very satisfactory because the distances between the distances of the sections measured on the vectorized maps and the validation maps are almost zero, less than $1 \%$. Nevertheless, a field visit would be more advantageous in the context of a more comprehensive study. About the evolution of the riverbed, illegal gold panning could be the cause of the increase in the surface area of the water body located between the SMI and the village of Floleu (Section 3). Indeed, this area is frequented daily by gold miners who carry out their activities both in the minor bed and on the banks of the river. [18] [27] argue that clandestine gold mining weakens soils, gradually destroys Arab lands, destabilizes banks and predisposes the soil to often intense erosion processes. Indeed, artisanal gold mining is generally accompanied by the opening of trenches, wells, scraping and turning the soil. Given the flow rate and flow velocity of the Cavally River, the presence of these trenches would indeed favor the erosion of the banks and therefore the deformation of the bed of the watercourse.

\section{Conclusion}

This study showed that the vegetation cover has deteriorated considerably (four common land use classes were finally mapped). They are represented by dense vegetation (13.11\%; degraded vegetation and crops (72.04\%); water (4.73\%); built areas and bare soils $(10.12 \%)$ ), the climate has been highly variable with a succession of dry and wet periods. The Cavally River watershed is subject to significantly hydro-climatic variability. This variability could have a significant impact on the water resources of the watershed. In recent years (2011s to 2018s), the Cavally River bed has undergone very significant modifications due to the massive presence of illegal gold panners operating in the bed with a degradation surface ranging from $13.70 \%$ between 1986 and 2011 to $55.00 \%$ between 2011 and 2018. Given the importance of the flows and flow rates of the Cavally River, the presence of trenches dug by these illegal gold panners would favor the erosion of the banks and therefore the deformation of the bed of the watercourse.

\section{Conflicts of Interest}

The authors declare no conflicts of interest regarding the publication of this paper.

\section{References}

[1] Zhai, X., Xia, J. and Zhang, Y. (2014) Water Quality Variation in the Highly Dis- 
turbed Huai River Basin, China from 1994 to 2005 by Multi-Statistical Analyses. Science of the Total Environment, 496, 594-606. https://doi.org/10.1016/j.scitotenv.2014.06.101

[2] Sundaray, S.K., Panda, U.C., Nayak, B.B. and Bhatta, D. (2006) Multivariate Statistical Techniques for the Evaluation of Spatial and Temporal Variations in Water Quality of the Mahanadi River-Estuarine System (India)-A Case Study. Environmental Geochemistry and Health, 28, 317-330.

https://doi.org/10.1007/s10653-005-9001-5

[3] Li, S., Xia, X., Tan, X. and Zhang, Q. (2013) Effects of Catchment and Riparian Landscape Setting on Water Chemistry and Seasonal Evolution of Water Quality in the Upper Han River Basin, China. PLoS ONE, 8, e53163.

https://doi.org/10.1371/journal.pone.0053163

[4] Vegas, M., Pardo, R., Barrado, E. and Deban, L. (1998) Assessment of Seasonal and Polluting Effects on the Quality of River Water by Exploratory Data Analysis. Water Research, 32, 3581-3592.

[5] Zhu, Z. and Wen, Q.X. (1994) Nitrogen in Soils of China. https://scholar.google.com/scholar lookup?title=Nitrogen $\% 20 \mathrm{in} \% 20$ soils $\% 20$ of $\% 20$ China\&author=Z.L.\%20Zhu\&publication year $=1994$

[6] Zhang, Y., Xia, J., Liang, T. and Shao, Q. (2010) Impact of Water Projects on River Flow Regimes and Water Quality in Huai River Basin. Water Resources Management, 24, 889-908. https://doi.org/10.1007/s11269-009-9477-3

[7] Mehran, A., et al. (2017) Compounding Impacts of Human-Induced Water Stress and Climate Change on Water Availability. Scientific Reports, 7, 6282.

https://doi.org/10.1038/s41598-017-06765-0

[8] Jun, X. and Beyaitan Bantin, A. (2017) The Impact of Hydro Climatic Variability on Water Resources of Lake Chad Hydro Graphic Basin. Hydrology: Current Research, 8. https://doi.org/10.4172/2157-7587.1000282

[9] Vorosmarty, C.J. (2000) Global Water Resources: Vulnerability from Climate Change and Population Growth. Science, 289, 284-288.

https://doi.org/10.1126/science.289.5477.284

[10] Milliman, J.D., Farnsworth, K.L., Jones, P.D., Xu, K.H. and Smith, L.C. (2008) Climatic and Anthropogenic Factors Affecting River Discharge to the Global Ocean, 1951-2000. Global and Planetary Change, 62, 187-194. https://doi.org/10.1016/j.gloplacha.2008.03.001

[11] Li, Y., He, D., Li, X., Zhang, Y. and Yang, L. (2016) Contributions of Climate Variability and Human Activities to Runoff Changes in the Upper Catchment of the Red River Basin, China. Water, 8, 414. https://doi.org/10.3390/w8090414

[12] Mekonnen, D.F., Duan, Z., Rientjes, T. and Disse, M. (2018) Analysis of Combined and Isolated Effects of Land-Use and Land-Cover Changes and Climate Change on the Upper Blue Nile River Basin's Streamflow. Hydrology and Earth System Sciences, 22, 6187-6207. https://doi.org/10.5194/hess-22-6187-2018

[13] Stryker, J., Wemple, B. and Bomblies, A. (2018) Modeling the Impacts of Changing Climatic Extremes on Streamflow and Sediment Yield in a Northeastern US Watershed. Journal of Hydrology: Regional Studies, 17, 83-94.

https://doi.org/10.1016/j.ejrh.2018.04.003

[14] Lutz, S.R., Mallucci, S., Diamantini, E., Majone, B., Bellin, A. and Merz, R. (2016) Hydroclimatic and Water Quality Trends across Three Mediterranean River Basins. Science of the Total Environment, 571, 1392-1406.

https://doi.org/10.1016/j.scitotenv.2016.07.102 
[15] Pandžić, K., Trninić, D., Likso, T. and Bošnjak, T. (2009) Long-Term Variations in Water Balance Components for Croatia. Theoretical and Applied Climatology, 95, 39-51. https://doi.org/10.1007/s00704-007-0366-5

[16] Lespinas, F., Ludwig, W. and Heussner, S. (2010) Impact of Recent Climate Change on the Hydrology of Coastal Mediterranean Rivers in Southern France. Climatic Change, 99, 425-456. https://doi.org/10.1007/s10584-009-9668-1

[17] Bauma, K.F. (2017) Etude sur l'utilisation du mercure et du cyanure dans l'exploitation artisanale de l'or au Nord et Sud-Kivu. Les voix de l'Est du Congo. Save Act Mine, 18.

[18] Bohbot, J. (2017) L'orpaillage au Burkina Faso: Une aubaine économique pour les populations, aux conséquences sociales et environnementales mal maîtrisées. EchoGéo, 42. https://doi.org/10.4000/echogeo.15150

[19] Tricart, J., et al. (1973) Une monographie physique de la Côte-d'Ivoire. Annales de Géographie, 82, 369-372. https://doi.org/10.3406/geo.1973.18905

[20] Charreton, B.M., Finch, J.W., Gresillon, J.M., Lamachère, J.M., Pallas, P. and Puech, C. (1995) Télédétection et gestion des ressources en eau. FAO, Atelier International, Montpellier, France.

[21] Ben Mammou, A. and Rabbi, M.C. (1990) L'imagerie satellitaire pour l'étude des réservoirs: applications à la retenue du barrage Sidi Salem (Tunisie), Satellite et gestion de l'eau au Sahel. Télédétection et cartographie, 2, 75-88.

[22] Yobouet, A. (2011) Contribution de l'imagérie satellitaire au suivi des ressources naturelles dans la partie Est du Burkina Faso. Mémoire Master, 2iE, Ouagadougou, Burkina Faso.

[23] Padonou, M.M.N. and Sarr, M.P. (2009) Contribution de la Télédétection et du Système d'Information Géographique (SIG) A l'amélioration de la gestion des eaux de surface dans un bassin versant: Cas du barrage de Mogtedo au Burkina Faso. Journées d'Animation Scientifique de I AUF, 7.

[24] Heinerich, S., Dejaifve, P.-A., Esquirol, N., LPO and ONF (2011) Cartographie du lit de la rivière Allier et de ses annexes dans la RNN du Val d'Allier, Reserve Naturelle Nationale du Val d'Allier. Reserve Naturelle de France, 22.

[25] Youan, T.M. (2008) Contribution de la télédétection et des systèmes d'informations géographiques à la prospection hydrogéologique du socle précambrien d'Afrique de l'ouest: Cas de la région de Bondoukou (nord-est de la côte d'ivoire). Thèse de doctorat, Université Félix Houphouët-Boigny, Abidjan-cocody, Cote d'Ivoire.

[26] Zro, B.G.F. (2012) Utilisation de la télédétection et du Système d'Information Géographique (SIG) pour la cartographie et l'évaluation de la fertilité rizicole des sols hydromorphes (gleysols): Cas d'un périmètre de la région du Bélier (Centre de la Côte d'Ivoire). Thèse de doctorat, Université Félix Houphouët-Boigny, Abidjan-Cocody, Cote d'Ivoire.

[27] Ouédraogo, I. (2012) Impact de l'exploitation minière industrielle sur la santé humaine et environnementale au Burkina Faso: Cas de la mine d'or de Essakane SA. Mémoire Master, Université de Versailles Saint Quentin en Yvelines, France. 